\title{
EFFECT OF CLIMATE VARIABILITY ON SORGHUM PRODUCTIVITY:PANEL DATA ANALYSIS
}

\section{PARTHASARATHI GURUSAMY ${ }^{1} \&$ BALASUBRAMANIAN RUDRASAMY ${ }^{2}$}

\author{
${ }^{I}$ Teaching Assistant (Agricultural Economics), Kumulur, Tiruchirappalli, Tamil Nadu, India \\ ${ }^{2}$ Professor (Agricultural Economics), Insitute of Agriculture, Kumulur, Tiruchirappalli, Tamil Nadu, India \\ ${ }^{2}$ Agricultural College and Research Institute, Vazhavachanur, Tamil Nadu, India
}

\section{ABSTRACT}

Sorghum is widely grown all parts of the world and it is consumed by all people. This paper studies the climate variabilityimpacton yield of sorghum crop in the state of Tamil Nadu using Panel regression analysis. The variables likeRainfall (max and min), Temperature (max and $\min$ ) and yield details werecollected and used for analysis. The study was taken in Tamil Nadu state of India. Panel regression was used to estimate crop production functions. The variables north east monsoon temperature and the square term of north east monsoon temperature are only significant. Since, the panel analysis shows there is relationship between temperature and sorghum yield.

KEYWORDS: Climate, Productivity Panel \& Agriculture

Received: Jul 09, 2020; Accepted: Jul 29, 2020; Published: Nov 10, 2020; Paper Id.: IJASRAUG202034

\section{INTRODUCTION}

Agriculture sector is an important sector in any country and in India around 60-70 per cent of the population depends directly or indirectly to agriculture. Climate change is an emerging concept directly affects the agricultural sector. It creates more challenges and problems in the field of agriculture and allied sciences. By the end of this century the temperature is likely to increase from 18. To 4.0 degree Celsius and it was projected by the IPCC in 2007. Climate variabilityaffecting rainfed crops like course cereals, pulses etc. Majority of the millets are sown in marginal lands and consumed by poor people. The millets are oldest crops domesticated by man for consumption. Thus a millet crop plays a major role in poor people diet. By the end of the 21 st century, it is estimated that, the rice productivity will decline by 10 per cent and sorghum productivity will decline by 9 per cent (Saravanakumar, 2015).Tamil Nadu is one among the major producer of millet crops, and majority of the farmers highly depends on millet crops for cultivation and consumption. Thus it is necessary to study the effect of climate variability. Sorghum is a staple food crop for many poor people in Asian region and semi-arid tropics of Africa. Sorghum is an important dry land crops grown in marginal land and a source of feed, fodder and biofuel apart from food. Hence, this study attempt to find out the effect of climate variability in Sorghum crop in the state of Tamil Nadu.

\section{METHODOLOGY}

\subsection{The Data}

The date on rainfall and temperature were collected for all the districts of Tamil Nadu from the year 1971 to 2010 from Indian Meteorological Department (IMD). The IMD weather stations are not present in every districts of Tamil Nadu. 
In that situation the data on rainfall and temperature were collected from the adjacent districts. The data on yield of sorghum was collected from the crop production reports of Tamil Nadu. Using the districts as panels, panel dataset was constructed using the district-wise time series data available over the period 1971 to 2010 .

\subsection{Panel Data Model}

Gupta et al. (2012) studied the climate change impacts on rice, sorghum and pearl millet in India and the results indicated significant impacts of climatic variables (temperature and precipitation) on rice, sorghum and pearl millet yield in India.To understand the impact of climate change on millet yield, the panel data model was used to estimate crop production functions. In the present study we have a balanced panel, as each district in the sample has 40 years of observations. This research used the below model with districts fixed effects and estimated using STATA software:

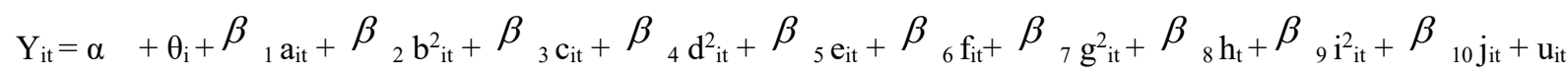

Where,

$$
\begin{aligned}
& \mathrm{Y}=\text { Yield of millet crops in district } \mathrm{i} \text { in year } \mathrm{t} \\
& \text { a } \quad=\quad \text { South West Monsoon Maximum Temperature in degree Celsius } \\
& \mathrm{b}^{2}=\text { Squared South West Monsoon Maximum Temperature in degree Celsius } \\
& \text { c } \quad=\quad \text { South West Monsoon Rainfall in Millimetres } \\
& \mathrm{d}^{2} \quad=\quad \text { Squared South West Monsoon Rainfall in Millimetres } \\
& \text { e } \quad=\text { Interaction term (SWM Rain* SWM Maximum Temperature) } \\
& \mathrm{f} \quad=\quad \text { North East Monsoon Maximum Temperature in degree Celsius } \\
& \mathrm{g}^{2} \quad=\quad \text { Squared North East Monsoon Maximum Temperature in degree Celsius } \\
& \mathrm{H}=\text { North East Monsoon Rainfall in Millimetres } \\
& \mathrm{i}^{2} \quad=\quad \text { Squared North East Monsoon Rainfall in Millimetres } \\
& \mathrm{j}=\text { Interaction term (NEM Rain* NEM Maximum Temperature) } \\
& \mathrm{U}_{\mathrm{it}}=\text { Error term. } \\
& \alpha \text { and } \beta_{1 \text { to }} \beta_{10} \text { are unknown parameters to be estimated } \\
& \theta_{\mathrm{i}}=\text { fixed effects for districts } \\
& i=\mathrm{i}^{\text {th }} \text { cross sectional units }\{\mathrm{i}=1,2,3,4 \text { (districts) }\} \text { and } \\
& t=t^{\text {th }} \text { time period }\{\mathrm{t}=1,2, \ldots, 39 \text { (years) }\}
\end{aligned}
$$

\subsection{Hausman Specification Test}

The Hausman specification test is necessary to find out whether we have to use the random effect model and fixed effect model. The Hausman test is intended to sensethe violation of assumption of random effects modelling that the independent variables are orthogonal to the unit effects. If the correlation is nil between the explanatory variable(s) and the unit effects, 
then values of $\beta$ in the fixed effects model ( $\left.\beta_{\mathrm{FE}}\right)$ should be alike to values of $\beta$ in the random effects model $\left(\beta_{\mathrm{RE}}\right)$.

The Hausman test statistic $(\mathrm{H})$ is a measure of the difference between the two estimates:

$\mathrm{H}=\left(\beta_{\mathrm{RE}}-\beta_{\mathrm{FE}}\right)\left[\operatorname{Var}\left(\beta_{\mathrm{FE}}\right)-\operatorname{Var}\left(\beta_{\mathrm{RE}}\right)\right]^{-1}\left(\beta_{\mathrm{RE}}-\beta_{\mathrm{FE}}\right)$

Under the null hypothesis of orthogonality, $\mathrm{H}$ is distributed chi-square with degrees of freedom equal to the number of independent variables in the model. In Hausman test, if the $\mathrm{p}$ value is $<0.05$ we can reject the random effects model and vice-versa.

\section{RESULTS}

The impact of climate variables on sorghum production was also estimated using district level panel data, with the districts serving as panels. The descriptive statistics of the variables used in the model are discussed below followed by the results of fixed effects panel data regression model.

\subsection{Descriptive Statistics}

The summary statistics of the climatic variables and sorghum yield used in the analysis are presented in Table 1 . The average productivity of sorghum was little more than one tonnes/ha and the standard deviation is $400 \mathrm{~kg} / \mathrm{ha}$. The mean level of rainfall (annual) over the 40 years was $965.56 \mathrm{~mm}$ per year and the standard deviation is $343 \mathrm{~mm}$. The mean level of annual temperature (max) was $33.03^{\circ} \mathrm{C}$ with the standard deviation of $1.07^{\circ} \mathrm{C}$.World Bank (2007) indicated that the frequency of rainfall has changed and increased in most of the regions and excessive temperature also noted in the earlier 50 years.

Table 1: Descriptive Statistics

\begin{tabular}{|c|c|c|c|c|c|c|}
\hline S. No & Variable & Unit & Mean & $\begin{array}{c}\text { Standard } \\
\text { Deviation }\end{array}$ & Maximum & Minimum \\
\hline 1. & Sorghum & $\mathrm{kg} / \mathrm{ha}$ & 1024 & 400 & 2337 & 162 \\
\hline 2. & Rainfall & Mm & 965.56 & 343.28 & 1927.30 & 281.5 \\
\hline 3. & Temperature (max) & Celsius & 33.04 & 1.07 & 35.26 & 30.53 \\
\hline
\end{tabular}

\subsection{Fixed Effects versus Random Effects Model}

To select the appropriate model the Hausman specification test was performed.

Table 2: Results of Hausman Specification Test

\begin{tabular}{|c|c|c|c|}
\hline Variables & Fixed Effects & Random Effects & Difference \\
\hline SWM Max Temp & -10.78 & -46.83 & 36.04 \\
\hline SWM Max Temp & 0.28 & 1.29 & -1.01 \\
\hline S Rain & -0.54 & 0.96 & -1.50 \\
\hline S Rain & $7.55 \mathrm{E}-05$ & -0.0001 & 0.0001 \\
\hline SRAINMAX & 0.01 & -0.01 & 0.02 \\
\hline NEM Max Temp & -279.47 & -497.001 & 217.52 \\
\hline NEM Max Temp & 5.48 & 9.71 & -4.23 \\
\hline N Rain & -1.53 & -1.73 & 0.19 \\
\hline N Rain & $5.19 \mathrm{E}-05$ & $-4.7 \mathrm{E}-05$ & $9.86 \mathrm{E}-05$ \\
\hline NRAINMAX & 0.05 & -0.01 \\
\hline
\end{tabular}


The Hausman test was run to find out the random versus fixed effects. The results indicated that the $p$ value is $<0.05$ and the null hypothesis is rejected and hence the random effects model was rejected. Since, the random effects model was rejected the fixed effects model were used for this research.

\subsection{Results of Panel Regression Model}

Table 3. presents the results of panel regression with districts fixed effects for sorghum crop.

Adamgbe and Ujoh (2012) studied the variations in climatic parameters and crop yield in Nigeria and find out that the factors like sunshine, temperature, rain, duration of rainy season, annual rain, onset of rain and end of rains influence the yield of various food crops. In that the climatic factorscreates 71 per cent variance in the yield of sorghum. Forty nine per cent variance in the yield of maize, forty eight per cent of variance in the yield of rice, thirty six per cent variance in the yield of groundnut, sixty per cent in the yield of soya and seventy eight per cent variance in the yield of yam. The coefficients of the NEM maximum temperature was negative and it was positive for its quadratic term, which indicates that sorghum yield has U-shaped response with NEM maximum temperature, implying that higher NEM maximum temperature would mean lower yield rates though at a decreasing rate.

\section{RESULTS OF PANEL REGRESSION MODEL FOR SORGHUM}

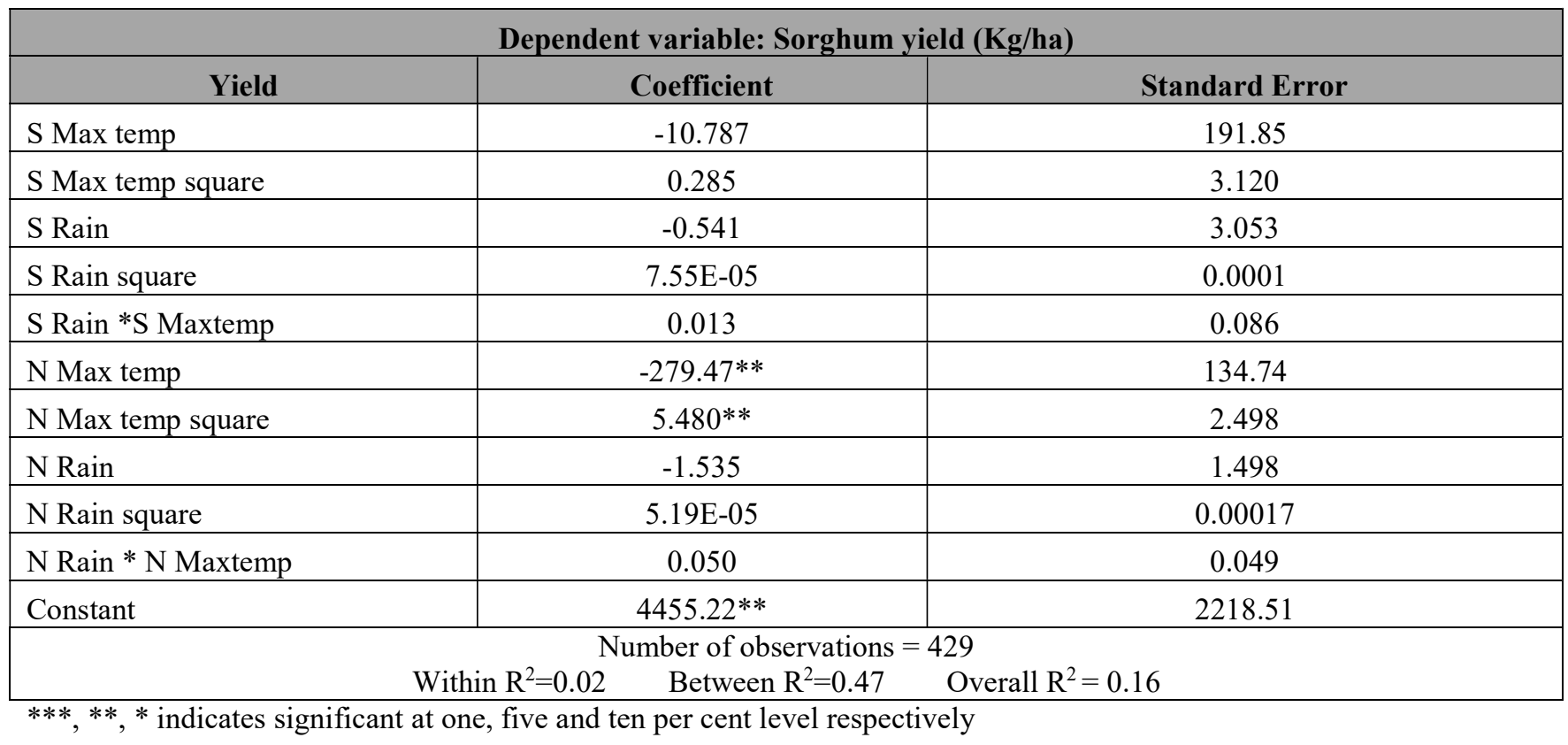

Except NEM maximum temperature and its quadratic term all the other variables were found insignificant for sorghum crop.Sultan et al. (2013)assessed the effects of climate change in the yield of sorghum and millet crops. The results indicate that the higher temperature reduced the yield of sorghum and increase evapotranspiration and reduced the crop cycle length.

\section{CONCLUSIONS}

In general, the millets are climate resilience crops, the response to climate change is insignificant. But recent results showed that for every degree of warning above a 1985-2014 average sorghum yield will drop by 10 per cent. The coefficients of SWM 
temperature, NEM temperature and the interaction terms between rainfall and temperature for sorghum crop stands positive. The sorghum yield has U-shaped response with NEM maximum temperature, implying that higher NEM maximum temperature would mean lower yield rates though at a decreasing rate. The North East Monsoon plays a significant role in millet production in Tamil Nadu, since this season provides high rainfall. The coefficient of north east monsoon maximum temperature and the interaction terms between north east rain and north east maximum temperature remains positive. This indicates, Tamil Nadu receives high rainfall during north east monsoon but along with the increase in temperature would increase the yield up to a certain level beyond that the yield will decrease.

\section{REFERENCES}

1. Adamgbe, M. Emmanuel and Fanan Ujoh, "Variations in Climatic Parameters and Food Crop Yields: Implications on Food Security in Benue State”, Confluence Journal of Environmental Studies, Kogi State University, Nigeria, 2012: 7: 59-67.

2. Bennaceur, Fatma, and Ali Bendob. "Crude Oil Prices and Banks Performance in the Arab Maghreb Countries (AlgeriaLibya-Tunisia-Morocco): Cross Section Analysis." International Journal of Financial Management (IJFM), ISSN (P) (2017).

3. Gupta. S., P. Sen and S. Srinivasan, "Impact of Climate Change on the Indian Economy: Evidence from Foodgrain Yields, Working Paper No. 218, Centre for Development 2012.

4. IPCC (Intergovernmental Panel on Climate Change). "Summary for Policymakers. In: Climate Change, (2007). Impacts, Adaptation and Vulnerability", Contribution of Working Group II to the Fourth Assessment Report of the Intergovernmental Panel on Climate Change, Parry, M. L., O. F. Canziani, J. P. Palutikof, P. J. van der Linden and C. E. Hanson (Ed.), Cambridge University Press, Cambridge, UK. 2007: 7-22.

5. Umar, MUHAMMAD SANI, and ATANDA TAIWO Mutiu. "A firm-level analysis of corporate governance and bank performance in Nigeria." International Journal of Business and General Management 5.3 (2016): 7-20.

6. Saravanakumar, "Impact of Climate Change on Yield of Major Food Crops in Tamil Nadu, India, South Asian Network for Development and Environmental Economics(SANDEE) Working Paper No.91-15, 2015.

7. Sultan B., P. Roudier, P. Quirion, A. Alhassane, B. Muller, M. Dingkhun, P. Ciais, M. Giumberteau, S. Traore and C. Baron, "Assessing Climate Change Impacts on Sorghum and Millet Yields in the Sudanian and Sahelian Savannas of West Africa”, Environment Research Letters, 2013: 8:1 9

8. Owolabi, J. D., et al. "Perspectives on Effectiveness of Gypsum Board over Sandcrete Block as Walling Material." International Journal of General Engineering and Technology (IJGET) 3.4 (2014): 1-10.

9. World Bank, Africa Rainfall and Temperature Evaluation System, World Bank, Washington D.C, 2003

10. Tamilselvan, M., and V. Manjula. "Price earnings ratio and financial performance Nexus using panel data regression model: The case of Oman." International Journal of Business Management \& Research (IJBMR) 6.2 (2016): 79-84.

11. Latifa, L. E. M. T. A. O. U. C. H., K. J. Yang, and R. R. Xu. "Economic growth and CO2 emissions Nexus in Algeria: A Cointegration analysis of the environmental Kuznets Curve." Int J Econ, Commer Res 4.4 (2014): 1-14. 

